\title{
Application of zinc and calcium acetate to precipitate milk fat globule membrane components from a dairy by-product
}

\author{
Nathan Price, ${ }^{1}$ Tao Fei, ${ }^{1,2}$ Stephanie Clark, ${ }^{1} \odot$ and Tong Wang ${ }^{1,2 *}$ (1) \\ ${ }^{1}$ Department of Food Science and Human Nutrition, lowa State University, Ames 50011-1061 \\ ${ }^{2}$ Department of Food Science, University of Tennessee, Knoxville 37996-4539
}

\begin{abstract}
There has been a great deal of interest in developing isolated dairy lipid fractions that are rich in phospholipids (PL), due to their health benefits and functional properties. Dairy by-products that contain elevated levels of PL and milk fat globule membrane (MFGM) proteins can be an excellent source for these isolates. The $\beta$ stream, a by-product of anhydrous milk fat production, is an excellent candidate because it contains a higher concentration of PL than many other dairy byproducts. In this study, we investigated an economically feasible processing method to obtain these valuable components from the $\beta$ stream. The use of zinc acetate and calcium acetate, along with mild heat treatment and $\mathrm{pH}$ adjustment, was effective in precipitating PL and proteins into a pellet fraction. With an additional extraction from the pellet using ethanol $\left(90 \%\right.$ at $\left.70^{\circ} \mathrm{C}\right)$, a PL-enriched lipid fraction was obtained. The effective precipitation conditions were zinc acetate of 25 $\mathrm{m} M$ concentration at $\mathrm{pH}$ greater than 6.5 at $30^{\circ} \mathrm{C}$, and calcium acetate of greater than $75 \mathrm{~m} M$ concentration at $\mathrm{pH}$ greater than 6.5 at $60^{\circ} \mathrm{C}$. With ethanol extraction, PL recovery of $97.7 \pm 1.7 \%$ from the zinc acetate precipitate and $94.9 \pm 3.7 \%$ from calcium acetate precipitate were achieved.
\end{abstract}

Key words: dairy lipid, ${ }^{31} \mathrm{P}$ nuclear magnetic resonance, sphingomyelin, phospholipids, ethanol extraction

\section{INTRODUCTION}

The milk fat globule membrane (MFGM) and its components have attracted significant interest because of potential health benefits and functional properties. This membrane encompasses the triacylglycerol fat globule and is the richest source of phospholipids $(\mathbf{P L})$, glycolipids, gangliosides, and glycoproteins in milk (Jimenez-Flores and Brisson, 2008). Although dairy PL

Received May 1, 2019.

Accepted September 3, 2019.

*Corresponding author: twang46@utk.edu represent only 0.5 to $1.0 \%$ of total milk lipids (Fong et al., 2007), they are of particular interest because of their higher levels of sphingomyelin (SM; 4.1 to $29.2 \%$ of total PL) and phosphatidylserine (PS; 2.0 to $16.1 \%$ of total PL) compared with other PL sources such as soybeans or egg yolk (Burling and Graverholt, 2008; Contarini and Povolo, 2013). Reported to play important roles in cell regulation, $\mathrm{SM}$ is referred to as a tumor suppressor (Rombaut et al., 2006; Dewettinck et al., 2008; Contarini and Povolo, 2013). Cognitive performance improvement, which is of a particular significance to Alzheimer's disease treatment, has been attributed to PS (Pepeu et al., 1996; Rombaut and Dewettinck, 2006; Burling and Graverholt, 2008; Dewettinck et al., 2008; Contarini and Povolo, 2013).

The use of salts, such as calcium chloride and zinc acetate, to precipitate MFGM components has been reported for dairy whey by-products (Rombaut and Dewettinck, 2007; Damodaran, 2010). These salts can precipitate MFGM components such as PL and proteins before ultrafiltration, to increase processing efficiency and prevent fouling of membranes during whey protein concentrate (WPC) production (Rombaut and Dewettinck, 2007). If the MFGM components are not removed from whey, the resulting WPC can develop a stale or oxidized off-flavor and brown discoloration during storage due to a series of complex and inter-related chemical reactions that include lipid oxidation and Maillard browning (Morr and Ha, 1991). These off-flavors can limit the use of WPC in the food industry (Carunchia Whetstine et al., 2005) and reduce the functionality of WPC by leading to high turbidity, impaired foaming, and reduced emulsification properties (Damodaran, 2005). These drawbacks have led to research focusing on the removal of MFGM components from whey. The application of salts to dairy by-products other than whey has yet to be investigated.

The $\beta$ stream is a by-product of anhydrous milk fat production that has a composition similar to buttermilk and butter serum. The starting material for the $\beta$ stream is cream, which is further processed into anhydrous milk fat. There are differences in the composition 
of the $\beta$ stream compared with whey by-products, in that the $\beta$ stream contains a higher protein content and a different protein profile. Casein is present in the $\beta$ stream but not in whey by-products, as it is removed during the cheese making process. There is also less lactose in the $\beta$ stream (43.6\%). Working with the higher amount of protein present in the $\beta$ stream will provide insight into how well the $\beta$ stream proteins and lipid fractions are precipitated during the salt precipitation step of the extraction process.

Application of calcium chloride (Rombaut and Dewettinck, 2007) and zinc acetate (Damodaran, 2010) has shown a great potential to remove dairy PL and MFGM components from whey by-products. Both salts were used, in combination with temperature and $\mathrm{pH}$ adjustments, to precipitate the MFGM components present in whey by-products. However, an efficient and economical lipid extraction for the precipitated pellet has yet to be developed to obtain PL. Rombaut and Dewettinck (2007) attempted to use a water wash to remove lactose and other water-soluble components from the pellet, but PL losses ranging from 16.6 to 49.7\% were observed. A novel approach to extract the $\mathrm{PL}$ in the pellet is to use ethanol for solubilizing the lipid and to precipitate the protein (Price et al., 2018). With such an ethanol extraction of the precipitate, it is important to understand the apparent solubility of each salt in ethanol. Calcium chloride has high ethanol solubility, whereas acetate salts have much lower ethanol solubility (Sheftel, 2000). Considering these factors, an investigation into the use of zinc acetate and calcium acetate on the $\beta$ stream was performed to determine how efficiently the total lipid, total PL, and protein are precipitated, and then the effectiveness of PL extraction with ethanol.

The specific aim of this investigation was to determine the practical and effective salt concentration and $\mathrm{pH}$ for the precipitation of both PL and proteins. Each individual PL class was quantified to evaluate the effect of these treatments on their recovery. The apparent solubility of each salt under various ethanol concentrations and temperatures was also determined, to ascertain what ethanol extraction parameters are best suited to limit the amount of salt being solubilized during the extraction. Then the application of ethanol to remove the total lipid and PL from the precipitate was evaluated.

\section{MATERIALS AND METHODS}

The $\beta$ stream powder used in this study was provided by Valley Queen Cheese (Milbank, SD). The extracted lipid was quantified for PL using ${ }^{31} \mathrm{P}$ nuclear magnetic resonance (NMR; Wang et al., 2014; Price et al., 2018). Reagent-grade solvents and other chemicals were purchased from Thermo Fisher Scientific (Fair Lawn, NJ) and Sigma-Aldrich (St. Louis, MO).

\section{Sample Preparation}

The $\beta$ stream powder was dispersed in deionized water (5\% wt/wt) and allowed to hydrate for $4 \mathrm{~h}$ under constant agitation (450 rpm). The $\mathrm{pH}$ of the dispersion was 4.7 , and $2 M$ sodium hydroxide solution was used to adjust the $\mathrm{pH}$ to a specific value ( $\mathrm{pH}$ monitored using Thermo Fisher Scientific Orion Star A111 pH meter). After hydration, powdered zinc acetate or calcium acetate was added at the designed molar concentration $(0,25,50,75,100,150$, and $200 \mathrm{~m} M)$. An exception was made for studying the effect of $\mathrm{pH}$ on the efficiency of lipid recovery, wherein the $\mathrm{pH}$ was adjusted after zinc acetate or calcium acetate addition, because these salts can lower the $\mathrm{pH}$ of the $\beta$ stream dispersion (Figure 1). The samples were then placed in a hot water bath (Thermo Fisher Scientific, model 3582) at 30 or $60^{\circ} \mathrm{C}$ for $30 \mathrm{~min}$. After this heat treatment, the samples were centrifuged (IEC Centra CL-2, Thermo Fisher Scientific) at $1,800 \times g$ for 5 min at ambient temperature. The samples were then allowed to cool overnight in the refrigerator $\left(2\right.$ to $\left.4^{\circ} \mathrm{C}\right)$, and the supernatant was then decanted and the lower pellet collected for total lipid extraction and PL quantification. The transmittance of the supernatant was measured at $500 \mathrm{~nm}$ using a Beckman Coulter (Brea, CA) DU 720 spectrophotometer as an indicator of effective MFGM precipitation.

\section{Analytical Methods}

Moisture and ash contents were determined by drying at $95^{\circ} \mathrm{C}$ for $24 \mathrm{~h}$ in a drying oven, and incineration in a muffle furnace (Barnstead Thermolyne 48000 Furnace model no. F48015, Waltham, MA) at $600^{\circ} \mathrm{C}$ for $24 \mathrm{~h}$. The Dumas (CHN-2000; Leco, St. Joseph, MI) method was used to quantify protein content in the initial $\beta$ stream powder and in the precipitated pellet. The protein concentration in the supernatant was assayed using the Bradford method (Bradford, 1976). Bovine serum albumin was used to establish a standard curve, and protein concentrations were reported as milligrams per milliliter. Protein distribution (initial $\beta$ stream, zinc acetate and calcium acetate-precipitated pellets, and supernatant) were assessed qualitatively using SDS-PAGE under reducing conditions, as described by Primacella et al. (2018). Individual proteins 
were identified using an SDS-PAGE molecular weight broad range standard (Bio-Rad laboratories, Hercules, $\mathrm{CA}$ ), and protein bands were identified according to the profile reported by Mather (2000). The MFGM-salt complex would not dissolve in water, so a $0.2 \%$ EDTA solution was used to release the MFGM into the dispersion before SDS-PAGE. Total lipid extraction using the Folch method (Folch et al., 1957; Rodriguez-Alcalá and Fontecha, 2010) was performed to quantify the lipid content in the $\beta$ stream and the precipitates. The PL content and the class composition of the lipid extracts were determined by using ${ }^{31} \mathrm{P}$ NMR, following a method reported by Price et al. (2018) and Wang et al. (2014).

\section{Zinc Acetate and Calcium Acetate Apparent Solubility in Ethanol}

The apparent solubility of each salt was determined by adding $10 \mathrm{~mL}$ of ethanol $(70,80$, and $90 \% \mathrm{vol} / \mathrm{vol})$ to $5 \mathrm{~g}$ of zinc acetate or calcium acetate. The sample vials were then capped and placed into a Thermo Fisher Scientific MaxQ 4450 heated shaker at 30, 50, and $70^{\circ} \mathrm{C}$ under constant agitation $(200 \mathrm{rpm})$ for $24 \mathrm{~h}$. The solubilized salts in ethanol were then decanted, and the ethanol was removed to determine how much salt was solubilized in the ethanol. The results were reported as grams of salt dissolved in $100 \mathrm{~g}$ of ethanol under the various ethanol concentrations and temperatures investigated.

\section{Ethanol Extraction of Lipids from the Pellets}

Once the pellet was recovered, the lipid was extracted using ethanol, according to Price et al. (2018). The optimum conditions for total lipid and PL recovery using a 1-step extraction were reported as $90 \%$ ethanol at $70^{\circ} \mathrm{C}$, and these conditions were used to extract the lipid from the $\beta$ stream pellet. The pellet ( $25 \mathrm{~g}$, as is) was placed in $206 \mathrm{~mL}$ of neat ethanol for zinc acetate and $198 \mathrm{~mL}$ of $100 \%$ ethanol for calcium acetate. The difference in total solids percentage between the zinc acetate and calcium acetate pellets led to slightly different volumes of ethanol required to achieve a final ethanol concentration of $90 \%$. After the pellet was in contact with the ethanol, incubation was allowed for 6 min before the ethanol with solubilized lipid was filtered to remove the residual pellet fraction. The ethanol was then rotary evaporated (Buchi Rotavapor R-205, New Castle, DE) to collect the lipid fraction. The residual pellet fraction was also recovered and saved for further analysis.

\section{Statistical Analysis}

All the treatments were randomized, with 3 replicates. The data were analyzed using SAS 9.1 software (SAS Institute Inc., Cary, NC), and the differences in treatment means and significance were evaluated at $P=0.05$ among all the treatments analyzed. The standard deviation from the mean was calculated for

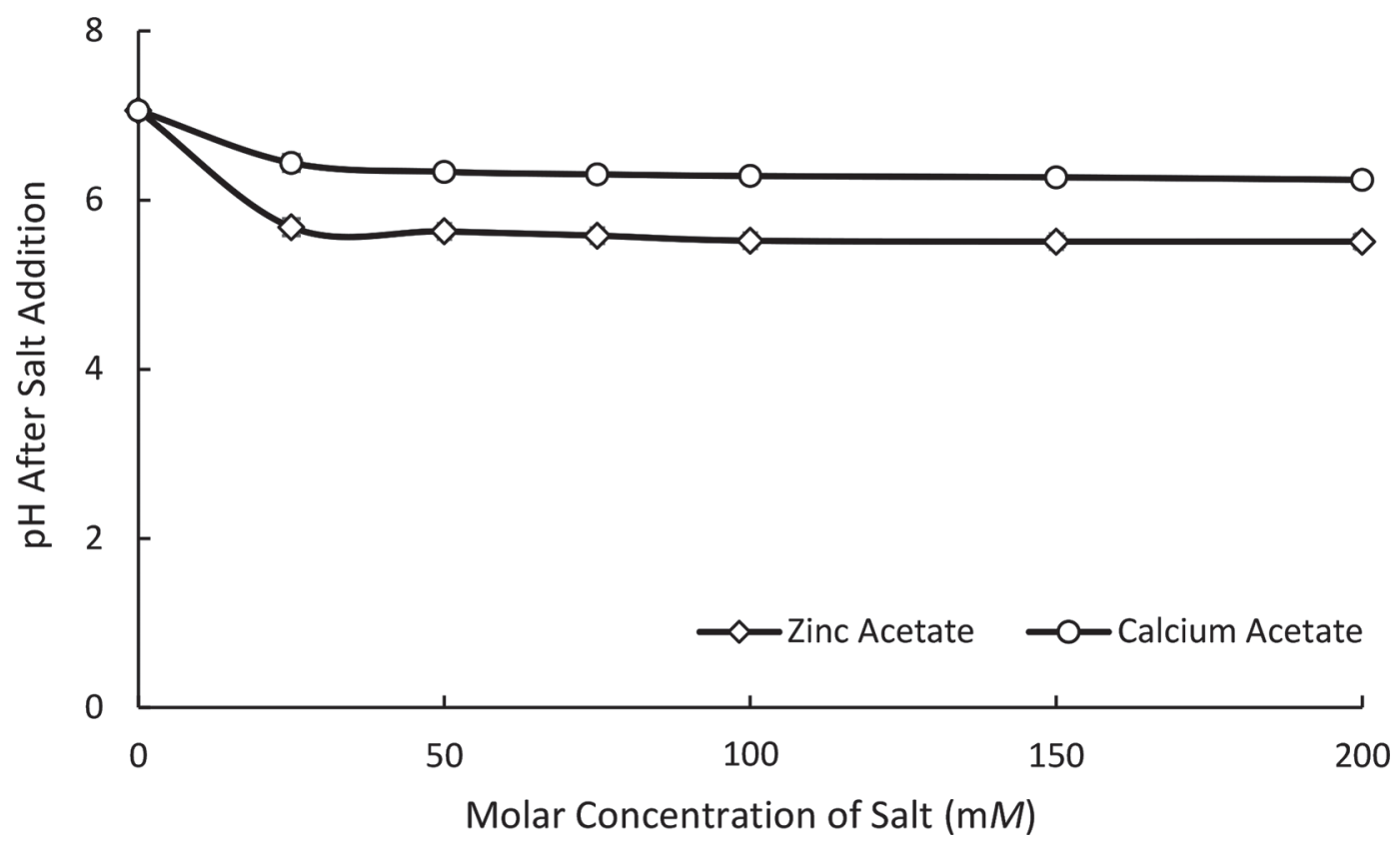

Figure 1. The $\mathrm{pH}$ of the $\beta$ stream (5\% dispersion) as affected by salt concentration before heat treatment. 
Table 1. Total lipid recovery, phospholipid (PL) recovery, and PL class composition (\% of total PL) $)^{1}$ for zinc acetate at $30^{\circ} \mathrm{C}$ and calcium acetate at 30 and $60^{\circ} \mathrm{C}$ treatments under various salt concentrations

\begin{tabular}{|c|c|c|c|c|c|c|c|c|}
\hline Treatment & $\begin{array}{c}\text { Total lipid } \\
\text { recovery }(\%)\end{array}$ & $\begin{array}{c}\mathrm{PL} \\
\text { recovery }(\%)\end{array}$ & $\mathrm{SM}$ & $\mathrm{PE}$ & PS & PI & $\mathrm{PC}$ & $\begin{array}{l}\text { PL (\% of } \\
\text { total lipid) }\end{array}$ \\
\hline Control, $30^{\circ} \mathrm{C}$ & $12.9^{\mathrm{ef}}$ & $10.0^{\mathrm{gh}}$ & $32.2^{\mathrm{a}}$ & $24.3^{\mathrm{c}}$ & $2.4^{\text {cd }}$ & $6.9^{\mathrm{a}}$ & $34.3^{\mathrm{a}}$ & $12.3^{\mathrm{bc}}$ \\
\hline $\mathrm{Zn} 25 \mathrm{~m} M, 30^{\circ} \mathrm{C}$ & $96.2^{\mathrm{a}}$ & $97.4^{\mathrm{a}}$ & $11.2^{\mathrm{de}}$ & $36.8^{\mathrm{ab}}$ & $8.6^{\text {bcde }}$ & $9.8^{\mathrm{a}}$ & $33.5^{\mathrm{b}}$ & $31.3^{\mathrm{a}}$ \\
\hline $\mathrm{Zn} 75 \mathrm{mM}, 30^{\circ} \mathrm{C}$ & $97.3^{\mathrm{a}}$ & $97.5^{\mathrm{a}}$ & $10.8^{\mathrm{e}}$ & $40.5^{\mathrm{a}}$ & $7.1^{\text {bcdef }}$ & $9.0^{\mathrm{a}}$ & $32.6^{\mathrm{b}}$ & $31.6^{\mathrm{a}}$ \\
\hline $\mathrm{Zn} 100 \mathrm{mM}, 30^{\circ} \mathrm{C}$ & $99.0^{\mathrm{a}}$ & $96.7^{\mathrm{a}}$ & $10.7^{\mathrm{e}}$ & $40.3^{\mathrm{ab}}$ & $7.5^{\text {bcdeg }}$ & $8.7^{\mathrm{a}}$ & $32.8^{\mathrm{b}}$ & $30.6^{\mathrm{a}}$ \\
\hline $\mathrm{Zn} 150 \mathrm{~m} M, 30^{\circ} \mathrm{C}$ & $98.9^{\mathrm{a}}$ & $93.8^{\mathrm{ab}}$ & $9.9^{\text {cde }}$ & $41.9^{\mathrm{a}}$ & $1.5^{\text {bcdef }}$ & $10.3^{\mathrm{a}}$ & $36.4^{\mathrm{ab}}$ & $34.4^{\mathrm{a}}$ \\
\hline $\mathrm{Ca} 50 \mathrm{~m} M, 30^{\circ} \mathrm{C}$ & $51.4^{\mathrm{cd}}$ & $48.6^{\text {ef }}$ & $27.7^{\mathrm{ab}}$ & $27.2^{\mathrm{bc}}$ & $0.6^{\mathrm{f}}$ & $10.7^{\mathrm{a}}$ & $33.4^{\mathrm{b}}$ & $27.0^{\mathrm{ab}}$ \\
\hline $\mathrm{Ca} 75 \mathrm{mM}, 30^{\circ} \mathrm{C}$ & $51.6^{\mathrm{cd}}$ & $56.6^{\text {def }}$ & $27.8^{\mathrm{ab}}$ & $28.1^{\text {abc }}$ & $1.1^{\mathrm{def}}$ & $10.3^{\mathrm{a}}$ & $32.7^{\mathrm{b}}$ & $30.4^{\mathrm{a}}$ \\
\hline $\mathrm{Ca} 100 \mathrm{~m} M, 30^{\circ} \mathrm{C}$ & $61.8^{\mathrm{bcd}}$ & $65.8^{\text {cde }}$ & $27.0^{\text {abcd }}$ & $28.6^{\mathrm{abc}}$ & $1.8^{\text {cdef }}$ & $10.0^{\mathrm{a}}$ & $32.6^{\mathrm{b}}$ & $31.1^{\mathrm{a}}$ \\
\hline Ca $150 \mathrm{mM}, 30^{\circ} \mathrm{C}$ & $73.5^{\mathrm{ab}}$ & $76.7^{\text {abcd }}$ & $20.2^{\text {abcde }}$ & $31.3^{\text {abc }}$ & $6.9^{\text {bcdef }}$ & $10.0^{\mathrm{a}}$ & $31.6^{\mathrm{b}}$ & $33.3^{\mathrm{a}}$ \\
\hline Ca $200 \mathrm{mM}, 30^{\circ} \mathrm{C}$ & $78.6^{\mathrm{ab}}$ & $80.3^{\text {abc }}$ & $21.4^{\text {abcde }}$ & $32.2^{\text {abc }}$ & $3.3^{\text {bcdef }}$ & $10.3^{\mathrm{a}}$ & $32.8^{\mathrm{b}}$ & $32.3^{\mathrm{a}}$ \\
\hline Control, $60^{\circ} \mathrm{C}$ & $10.7^{\mathrm{f}}$ & $3.6^{\mathrm{h}}$ & $35.0^{\mathrm{a}}$ & $3.9^{\mathrm{d}}$ & $18.4^{\mathrm{a}}$ & $0.0^{\mathrm{b}}$ & $42.7^{\mathrm{a}}$ & $8.4^{\mathrm{c}}$ \\
\hline $\mathrm{Ca} 25 \mathrm{~m} M, 60^{\circ} \mathrm{C}$ & $71.5^{\mathrm{abcd}}$ & $66.2^{\mathrm{bcd}}$ & $11.6^{\text {bcde }}$ & $33.4^{\text {abc }}$ & $7.6^{\text {bcdef }}$ & $11.1^{\mathrm{a}}$ & $36.2^{\mathrm{b}}$ & $30.3^{\mathrm{a}}$ \\
\hline
\end{tabular}

${ }^{\mathrm{a}-\mathrm{h}}$ Means with different superscript letters within the same column are significantly different at $P=0.05$.

${ }^{1} \mathrm{SM}=$ sphingomyelin; $\mathrm{PE}=$ phosphatidylethanolamine; $\mathrm{PS}=$ phosphatidylserine; $\mathrm{PI}=$ phosphatidylinositol; PC $=$ phosphatidylcholine.

all treatments (presented as error bars in figures). The Tukey test was used to analyze statistical differences among means.

\section{RESULTS AND DISCUSSION}

The $\beta$ stream powder contained $18.1 \%$ total lipid, of which $35.0 \%$ was PL $(6.3 \%$ on product basis). It contained $29.1 \%$ protein, $6.1 \%$ ash, $43.6 \%$ lactose, and $3.1 \%$ moisture. The major PL classes found in the $\beta$ stream were phosphatidylcholine (PC; $34.2 \%$ of total PL), phosphatidylethanolamine (PE; 28.0\%), and SM (27.0\%). The minor PL classes were PS (2.1\%) and phosphatidylinositol (PI; 8.7\%). The PL composition of the $\beta$ stream was similar to that of native milk fat (Contarini and Povolo, 2013).

\section{Effects of Calcium Acetate and Zinc Acetate Concentrations on Precipitation of Total Lipid, $P L$, and Protein}

Total lipid recovery, PL recovery, PL content, and PL class composition for the zinc acetate- and calcium acetate-precipitated samples are shown in Table 1. The concentration and type of salt were both significant factors for total lipid and PL recoveries $(P<0.05)$. All concentration treatments resulted in significantly more total lipid and PL recoveries compared with the control treatments $(P<0.05)$. We found no significant differences among the total lipid recoveries for the zinc acetate treatments $(P>0.05)$, which resulted in total lipid recovery ranging from 94.5 to $99.9 \%$ (25 to 200 $\mathrm{m} M)$. Treatment with calcium acetate $(25$ to $100 \mathrm{mM})$ at $30^{\circ} \mathrm{C}$ resulted in significantly less total lipid and PL recovery compared with the zinc acetate treatment, with total lipid recovery ranging from 41.6 to $61.8 \%$ and PL recoveries ranging from 36.5 to $65.8 \%$. The concentration of 150 to $200 \mathrm{~m} M$ resulted in significantly higher total lipid and PL recovery than did the lower salt concentration. At $60^{\circ} \mathrm{C}$, the 75 to $200 \mathrm{~m} M$ concentration range of calcium acetate led to similar total and PL recoveries compared with zinc acetate (88.4 to $97.9 \%$ total and 84.9 to $92.9 \%$ PL recoveries). The $30^{\circ} \mathrm{C}$ calcium acetate treatment resulted in significantly lower $(P<0.05)$ total and PL recoveries compared with the overall treatment means for zinc acetate or $60^{\circ} \mathrm{C}$ calcium acetate.

We discovered no significant difference in the PL contents of the precipitated total lipid fractions among any of the zinc acetate or calcium acetate treatments $(P>$ $0.05)$. All the treatments resulted in significantly higher PL contents (24.5 to $34.4 \%$ ) than did the control treatments (8.4 to $12.3 \%$ ). The PL class compositions for all 3 types of treatment were similar, with a few significant variations in the content of SM, PS, and $\mathrm{PE}$. The $30^{\circ} \mathrm{C}$ calcium acetate treatment as a whole resulted in significantly more SM recovery and less PS recovery than did the $60^{\circ} \mathrm{C}$ calcium acetate and zinc acetate treatments. 
The $60^{\circ} \mathrm{C}$ calcium acetate treatment resulted in seemingly higher PS recovery compared with zinc acetate. Zinc acetate led to a slightly higher PE recovery than did either of the calcium acetate treatments. The PL classes of specific interest are SM and PS because of their health benefits, and enrichment of these PL during extraction is desired. Therefore, the $30^{\circ} \mathrm{C}$ calcium acetate treatment would be desired for good SM recovery, but the $60^{\circ} \mathrm{C}$ calcium acetate treatment would be desired for maximum PS recovery. The difference in recovery of different PL classes may be attributed to the location of these PL within the MFGM, which may lead to a preference for complexing with calcium compared with zinc. The most polar PL class, SM, is located on the outer bilayer of the MFGM, whereas PS, a more nonpolar PL class, is more closely associated with the inner membrane (Deeth, 1997; Dewettinck et al., 2008; Christie and Han, 2010). Zinc acetate may interact more with the integral hydrophobic proteins of the MFGM and have a preference to bind to the MFGM inner membrane, as more PE was recovered using zinc acetate. Due to variations in PL class recovery under the temperature treatments investigated, we speculate that calcium acetate may not have a preference for specific areas in the MFGM.

Supernatant transmittance and protein concentrations were analyzed to give an indication of how salt concentrations affect precipitation of protein, and the results are summarized in Figures 2 and 3. Higher transmittance indicates that more protein or lipoprotein was precipitated into the pellet. As shown in Figure 4, a strong correlation exists between transmittance and protein concentration in the supernatant. As transmittance increased, we found less protein in the supernatant. Transmittance of all the supernatant from the zinc acetate treatments was significantly higher than that of the calcium acetate treatments, and the protein concentration in the supernatant was also significantly lower in calcium acetate treatments $(P<0.05)$. The zinc acetate treatment was more effective in removing lipoproteins from the supernatant and precipitating them into the pellet compared with the calcium acetate treatments. When the temperature of calcium acetate treatment was increased from 30 to $60^{\circ} \mathrm{C}$, significantly higher transmittance and lower protein concentrations in the supernatant were observed $(P<0.05)$. Increasing the temperature resulted in a better binding affinity of calcium with protein and lipid, but not to the extent of zinc acetate. This indicates that zinc acetate had a stronger affinity toward protein, and calcium acetate had a lower affinity toward protein but stronger affinity toward lipid. These results may be due to how zinc and calcium interact with MFGM components. Zinc forms a tetracoordination complex with membrane phospholipids in a tetrahedral geometry, whereas calcium forms a hexacoordination complex in an octahedral geometry

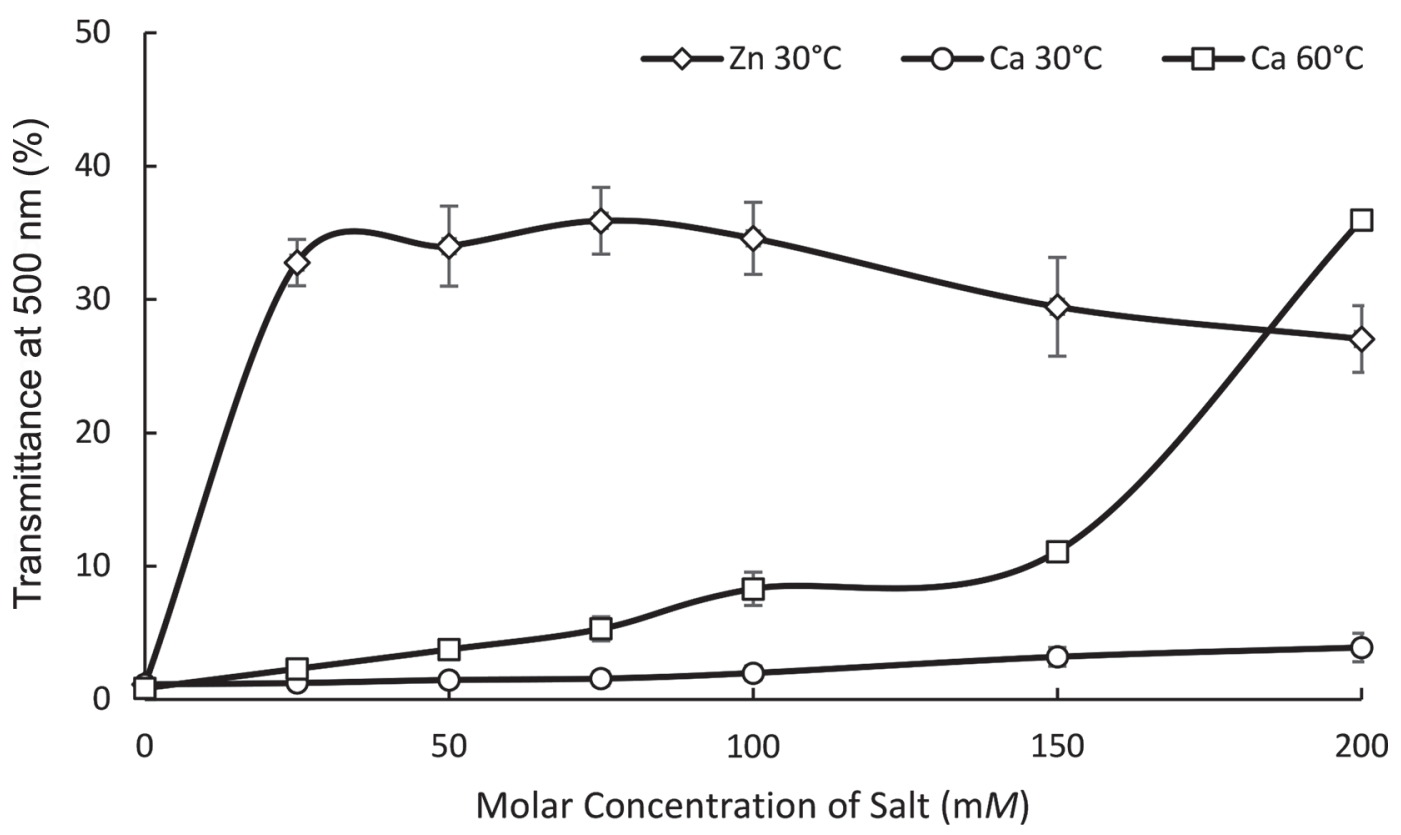

Figure 2. The effect of salt concentration and temperature on transmittance of the supernatant of the $5 \% \beta$ stream dispersion. Error bars represent $\mathrm{SD}$. 


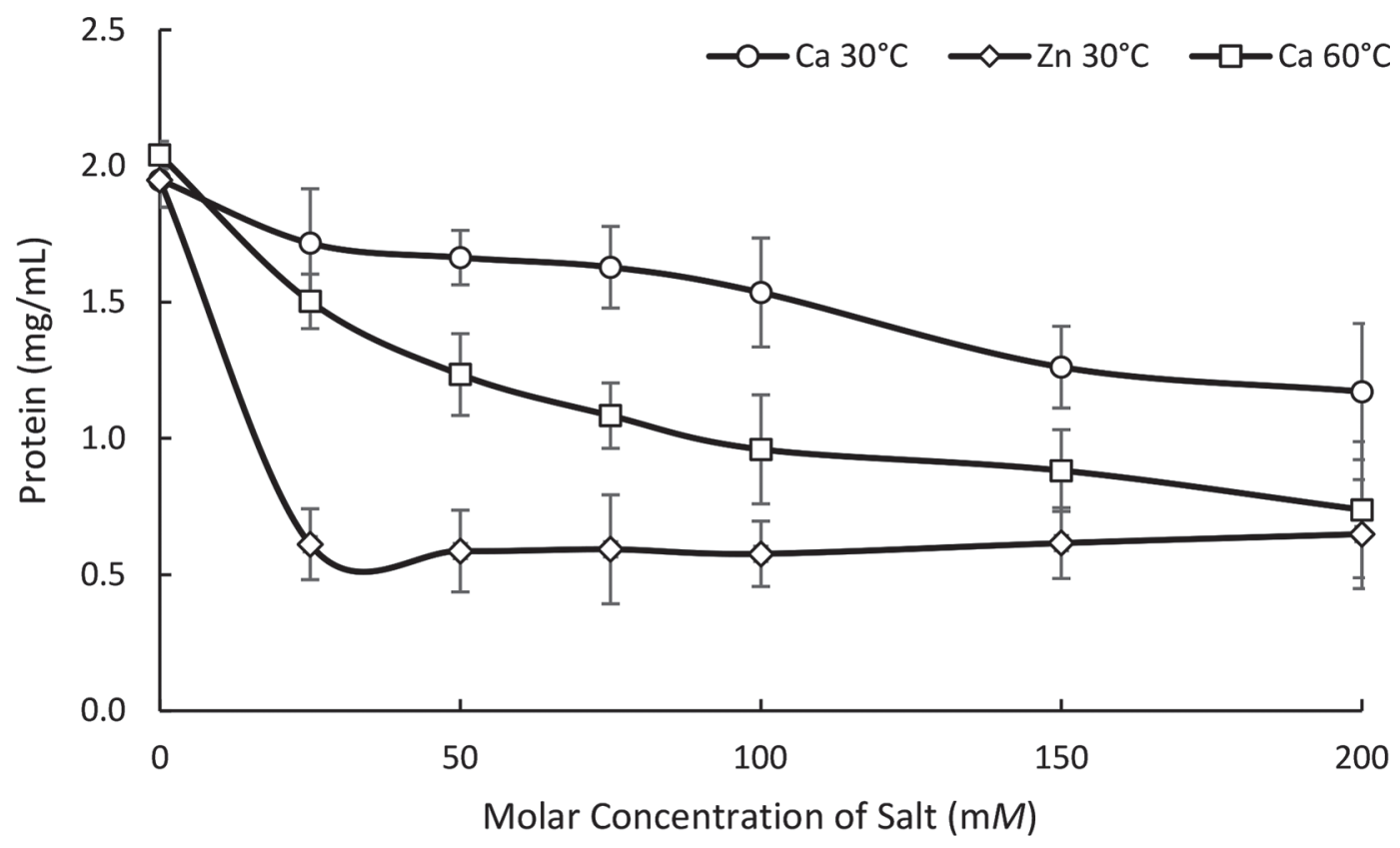

Figure 3. The effect of salt concentration and temperature treatment on the supernatant protein concentration (assayed with the Bradford method) of the $5 \% \beta$ stream dispersion. Error bars represent SD.

(Binder et al., 2001; D'Acapito et al., 2002; Damodaran, 2010). The differences in the geometry of the salt-MFGM complexes may lead to more opportunity for zinc to interact with the protein present in the $\beta$ stream.

\section{Effect of $\mathrm{pH}$ on the Efficiency of Total Lipid, PL, and Protein Precipitation}

An investigation to determine which $\mathrm{pH}$ is ideal for the effective and most practical zinc acetate treatment was performed using the salt concentration of $25 \mathrm{mM}$ at $30^{\circ} \mathrm{C}$. At this concentration, a $\mathrm{pH}$ range of 5.0 to 8.0 was investigated, to determine whether the $\mathrm{pH}$ of the $\beta$ stream had a significant effect on the recovery of total lipid, PL, and protein. We found no significant differences in the total lipid and PL recoveries among all the $\mathrm{pH}$ investigated for zinc acetate $(P>0.05)$. The numerically highest lipid recovery was seen for the $8.0 \mathrm{pH}$ treatment, with $98.1 \%$ total lipid and $98.2 \%$ total PL recovery (Table 2). These results indicate that zinc acetate had no preference for neutral lipid or PL under all $\mathrm{pH}$ conditions investigated. This can also be observed in the PL contents of the overall lipid fraction, which were similar to those of the initial $\beta$ stream $(35.0 \% \mathrm{PL})$. The highest-PL fraction was the $\mathrm{pH} 7.5$ treatment, with a PL content of $36.2 \%$, but this was not statistically significant. Additionally, we discovered no significant differences among PL composition of classes under the various $\mathrm{pH}$ conditions $(P>0.05)$.
Results for supernatant transmittance and protein concentrations, as affected by $\mathrm{pH}$, can be seen in Figure 5. As the $\mathrm{pH}$ increased, we found less protein in the supernatant, and a higher transmittance was observed. The $\mathrm{pH}$ of 6.5 and above yielded significantly higher transmittance than did the lower $\mathrm{pH}$ treatments $(P<$ $0.05)$. The lower transmittance at $\mathrm{pH}$ below 6.5 indicates that proteins were not precipitated as effectively under lower-pH conditions. Similar results were observed by Damodaran (2010), who investigated only the $\mathrm{pH}$ range below 6.5 and concluded that charge variations of membrane proteins as a function of $\mathrm{pH}$ can contribute to the net charge of MFGM and its interaction with zinc. The isoelectric point of most milk proteins is about $\mathrm{pH} 4.6$ to 5.2 (Fong et al., 2007), and at $\mathrm{pH}$ above this range (5.5 through 8.0) the charge on the proteins would be negative. The zinc ion has a positive charge; thus, better precipitation of protein and PL can be expected at $\mathrm{pH}$ above 5.2. The transmittance results observed in this study were higher than the results observed when the concentration of salt was studied. During this study, salt was added before $\mathrm{pH}$ adjustment (versus salt addition after $\mathrm{pH}$ adjustment during the salt concentration study) so there was a longer interaction time between the salt and MFGM components. This longer interaction time may have led to supernatant with increased transmittance and lower protein concentration.

For calcium acetate of $25 \mathrm{mM}$ at $60^{\circ} \mathrm{C}$, the $\mathrm{pH}$ significantly affected the total lipid and PL recoveries (Table 2). As the $\mathrm{pH}$ of the $\beta$ stream increased, higher 
Table 2. Total lipid recovery, phospholipid (PL) recovery, and PL composition (\% of total PL) ${ }^{1}$ from the $25 \mathrm{~m} M$ zinc acetate at $30^{\circ} \mathrm{C}$ and 25 $\mathrm{m} M$ calcium acetate at $60^{\circ} \mathrm{C}$ treatments under various $\mathrm{pH}$ levels

\begin{tabular}{|c|c|c|c|c|c|c|c|c|}
\hline Treatment & $\begin{array}{l}\text { Total lipid } \\
\text { recovery (\%) }\end{array}$ & $\begin{array}{c}\mathrm{PL} \\
\text { recovery }(\%)\end{array}$ & SM & $\mathrm{PE}$ & PS & PI & $\mathrm{PC}$ & $\begin{array}{c}\mathrm{PL}(\% \text { of } \\
\text { total lipid) }\end{array}$ \\
\hline $\operatorname{Zn} 5.0$ & $89.3^{\mathrm{abcd}}$ & $86.9^{\mathrm{abc}}$ & $11.7^{\text {abcd }}$ & $32.6^{\mathrm{a}}$ & $7.5^{\mathrm{a}}$ & $11.6^{\mathrm{ab}}$ & $36.6^{\mathrm{ab}}$ & $34.9^{\mathrm{a}}$ \\
\hline Zn 5.5 & $92.7^{\mathrm{abc}}$ & $87.9^{\mathrm{abc}}$ & $10.6^{\mathrm{bcd}}$ & $34.2^{\mathrm{a}}$ & $7.5^{\mathrm{a}}$ & $12.0^{\mathrm{a}}$ & $35.7^{\mathrm{ab}}$ & $33.9^{\mathrm{ab}}$ \\
\hline Zn 6.0 & $93.9^{\mathrm{abc}}$ & $90.9^{\mathrm{ab}}$ & $12.6^{\mathrm{abcd}}$ & $34.6^{\mathrm{a}}$ & $8.1^{\mathrm{a}}$ & $10.4^{\mathrm{ab}}$ & $34.3^{\mathrm{b}}$ & $34.6^{\mathrm{a}}$ \\
\hline $\operatorname{Zn} 6.5$ & $94.7^{\mathrm{ab}}$ & $93.1^{\mathrm{a}}$ & $12.3^{\mathrm{abcd}}$ & $34.7^{\mathrm{a}}$ & $6.8^{\mathrm{a}}$ & $10.6^{\mathrm{ab}}$ & $35.6^{\mathrm{ab}}$ & $35.2^{\mathrm{a}}$ \\
\hline Zn 7.0 & $96.6^{\mathrm{ab}}$ & $95.3^{\mathrm{a}}$ & $11.9^{\text {abcd }}$ & $33.8^{\mathrm{a}}$ & $7.5^{\mathrm{a}}$ & $10.9^{\mathrm{ab}}$ & $35.9^{\mathrm{ab}}$ & $34.9^{\mathrm{a}}$ \\
\hline $\operatorname{Zn} 7.5$ & $96.7^{\mathrm{ab}}$ & $96.9^{\mathrm{a}}$ & $11.5^{\mathrm{bcd}}$ & $33.7^{\mathrm{a}}$ & $7.6^{\mathrm{a}}$ & $11.3^{\mathrm{ab}}$ & $35.9^{\mathrm{ab}}$ & $36.2^{\mathrm{a}}$ \\
\hline $\operatorname{Zn} 8.0$ & $98.1^{\mathrm{a}}$ & $98.2^{\mathrm{a}}$ & $10.5^{\mathrm{bcd}}$ & $34.0^{\mathrm{a}}$ & $7.0^{\mathrm{a}}$ & $11.1^{\mathrm{ab}}$ & $37.4^{\mathrm{ab}}$ & $34.6^{\mathrm{a}}$ \\
\hline Ca 5.0 & $53.1^{\mathrm{e}}$ & $27.0^{\mathrm{e}}$ & $16.0^{\mathrm{ab}}$ & $24.1^{\mathrm{b}}$ & $8.2^{\mathrm{a}}$ & $11.2^{\mathrm{ab}}$ & $40.5^{\mathrm{a}}$ & $19.6^{\mathrm{de}}$ \\
\hline Ca 5.5 & $50.3^{\mathrm{e}}$ & $24.4^{\mathrm{e}}$ & $17.0^{\mathrm{a}}$ & $24.5^{\mathrm{b}}$ & $6.5^{\mathrm{a}}$ & $10.7^{\mathrm{ab}}$ & $41.4^{\mathrm{a}}$ & $19.0^{\mathrm{e}}$ \\
\hline Ca 6.0 & $54.6^{\mathrm{e}}$ & $32.8^{\mathrm{e}}$ & $17.1^{\mathrm{a}}$ & $24.0^{\mathrm{b}}$ & $7.1^{\mathrm{a}}$ & $10.9^{\mathrm{ab}}$ & $40.8^{\mathrm{a}}$ & $22.4^{\mathrm{d}}$ \\
\hline $\mathrm{Ca} 6.5$ & $80.0^{\mathrm{d}}$ & $63.9^{\mathrm{d}}$ & $12.0^{\text {abcd }}$ & $34.0^{\mathrm{a}}$ & $7.4^{\mathrm{a}}$ & $10.5^{\mathrm{ab}}$ & $36.1^{\mathrm{ab}}$ & $28.5^{\mathrm{c}}$ \\
\hline $\mathrm{Ca} 7.0$ & $81.9^{\mathrm{d}}$ & $75.3^{\mathrm{bcd}}$ & $14.5^{\mathrm{abc}}$ & $33.4^{\mathrm{a}}$ & $6.5^{\mathrm{a}}$ & $9.5^{\mathrm{b}}$ & $36.0^{\mathrm{ab}}$ & $31.2^{\mathrm{bc}}$ \\
\hline $\mathrm{Ca} 7.5$ & $83.9^{\mathrm{cd}}$ & $73.6^{\mathrm{cd}}$ & $10.1^{\mathrm{cd}}$ & $36.3^{\mathrm{a}}$ & $6.7^{\mathrm{a}}$ & $9.7^{\mathrm{b}}$ & $37.2^{\mathrm{ab}}$ & $31.1^{\mathrm{bc}}$ \\
\hline Ca 8.0 & $84.3^{\mathrm{bcd}}$ & $68.8^{\mathrm{d}}$ & $7.9^{\mathrm{d}}$ & $35.5^{\mathrm{a}}$ & $7.0^{\mathrm{a}}$ & $10.9^{\mathrm{ab}}$ & $38.7^{\mathrm{ab}}$ & $28.4^{\mathrm{c}}$ \\
\hline
\end{tabular}

${ }^{\mathrm{a}-\mathrm{e}}$ Means with different superscript letters within the same column are significantly different at $P=0.05$.

${ }^{1} \mathrm{SM}=$ sphingomyelin; $\mathrm{PE}=$ phosphatidylethanolamine; PS $=$ phosphatidylserine; $\mathrm{PI}=$ phosphatidylinositol; PC $=$ phosphatidylcholine.

total lipid and PL recoveries were observed, and the $\mathrm{pH}$ range of 6.5 to 8.0 resulted in significantly higher total lipid, PL recovery, and PL content in the lipid fraction $(P<0.05)$. The PL content of calcium acetate treatments were significantly lower compared with the zinc acetate treatment $(P<0.05)$, indicating that calcium acetate did not bind PL as effectively as zinc acetate, or that binding was stronger to other non-PL components. With calcium acetate, $\mathrm{pH}$ also had a significant effect on PL class composition. It was observed that significantly more $(P<0.05) \mathrm{SM}$ was recovered in the $\mathrm{pH}$ range of 5.0 to 6.0 , and significantly more $(P<$ $0.05) \mathrm{PC}$ was recovered at the $\mathrm{pH}$ range of 5.0 to 6.0. Significantly more $(P<0.05) \mathrm{PE}$ was recovered at the $\mathrm{pH}$ range of 6.5 to 8.0.

The protein concentration and transmittance results for the calcium acetate treatment under various $\mathrm{pH}$ conditions can be seen in Figure 5. Transmittance of the calcium acetate supernatant was significantly higher in the $\mathrm{pH}$ range of 7.0 to $8.0(P<0.05)$. This

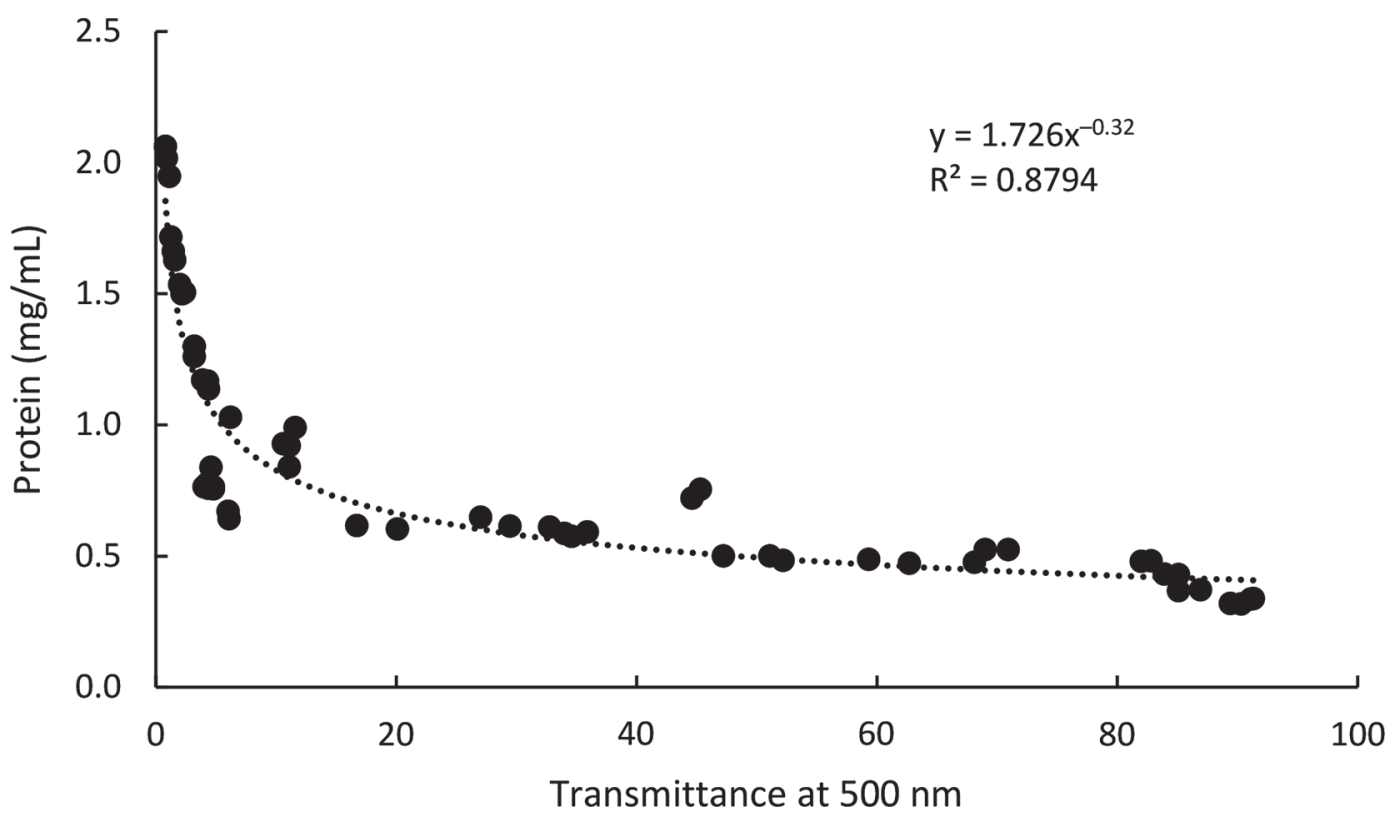

Figure 4. Power-Law correlation between protein concentration and transmittance of the supernatant from all treatments examined in this study. 
$\mathrm{pH}$ range also resulted in significantly lower protein concentration in the supernatant $(P<0.05)$. The $\mathrm{pH}$ range of 5.0 to 6.0 resulted in a supernatant with significantly higher protein concentration $(P<0.05)$. The protein charge under the various $\mathrm{pH}$ treatments had a profound effect on how efficiently MFGM proteins were precipitated into the pellet.
Apparent Solubility of Zinc Acetate and Calcium Acetate in Ethanol for Extracting Lipids

from the Pellet

The apparent solubility of zinc acetate and calcium acetate under 3 different ethanol concentrations (70, 80 , and $90 \% \mathrm{vol} / \mathrm{vol}$ ) and 3 different temperatures
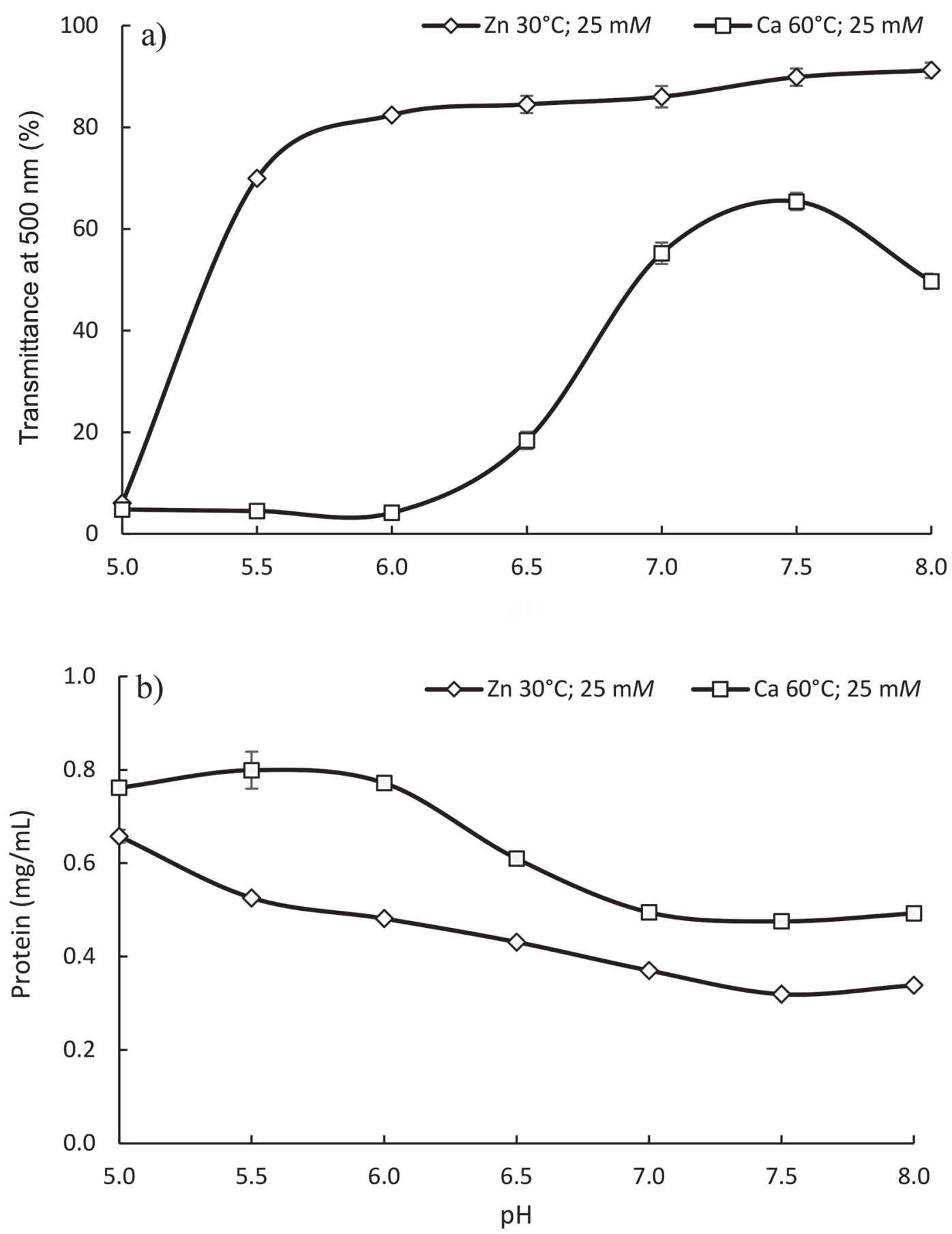

Figure 5. The transmittance (a) and protein concentration (b) of the $\beta$ stream supernatant treated with zinc acetate at $25 \mathrm{~m} M$ and $30^{\circ} \mathrm{C}$ and calcium acetate at $25 \mathrm{mM}$ and $60^{\circ} \mathrm{C}$ under various $\mathrm{pH}$ conditions. Error bars represent SD. 
$\left(30,50\right.$, and $\left.70^{\circ} \mathrm{C}\right)$ were investigated, to determine the potential quantity of each salt that can be solubilized during ethanol lipid extractions. The results are shown in Table 3. It is apparent that the temperature and type of salt were significant factors for their solubility in ethanol $(P<0.05)$. Zinc acetate is significantly more soluble than calcium acetate in ethanol $(P<0.05)$. The temperature of $70^{\circ} \mathrm{C}$ solubilized significantly more salt compared with 30 and $50^{\circ} \mathrm{C}(P<0.05)$, whereas the concentration of ethanol was not a significant factor. Because ethanol at higher concentration had a slightly lower salt solubility, an ethanol concentration of $90 \%$ was used for the ethanol extraction. Previous work with whey protein phospholipid concentrate showed that an ethanol concentration of $90 \%$ at $70^{\circ} \mathrm{C}$ was optimal for a 1-step total lipid extraction (Price et al., 2018). Under such conditions, $0.5 \mathrm{~g}$ of calcium acetate and $22.7 \mathrm{~g}$ of zinc acetate can be solubilized in $100 \mathrm{~g}$ of ethanol.

The precipitation treatments used for the ethanol extraction from the $\beta$ stream pellets were $25 \mathrm{mM}, \mathrm{pH}$ 7.5 , and $30^{\circ} \mathrm{C}$ for zinc acetate and $100 \mathrm{mM}, \mathrm{pH} 7.5$, and $60^{\circ} \mathrm{C}$ for calcium acetate. The zinc acetate-precipitated pellet contained $0.9 \%$ total lipid $[10.5 \%$ dry basis (DB)], $0.3 \%$ PL $(3.6 \%$ DB), $3.2 \%$ protein $(37.2 \%$ DB), $2.6 \%$ lactose $(31.4 \% \mathrm{DB})$, and $1.8 \%$ ash $(20.9 \% \mathrm{DB})$, with a total solids content of $8.6 \%$. The PL content of the pellet was $36.2 \%$ of its total lipid, which was composed of $35.9 \% \mathrm{PC}, 33.7 \% \mathrm{PE}, 11.5 \% \mathrm{SM}, 11.3 \% \mathrm{PI}$, and $7.6 \%$ PS. The calcium acetate-precipitated pellet contained $0.8 \%$ total lipid $(6.6 \% \mathrm{DB}), 0.3 \% \mathrm{PL}(2.3 \%$ DB), $4.6 \%$ protein $(38.0 \%$ DB), $2.8 \%$ lactose $(23.1 \%$ $\mathrm{DB})$, and $3.9 \%$ ash $(32.2 \% \mathrm{DB})$, with a total solids content of $12.1 \%$. The PL content of this pellet was $31.2 \%$ of its total lipid, which was composed of $38.3 \% \mathrm{PE}$, $34.2 \%$ PC, $10.0 \%$ SM, $9.7 \%$ PI, and $7.8 \%$ PS. The calcium acetate-precipitated pellet contained significantly higher ash and total solids content than did the zinc acetate pellet $(P<0.05)$. The usage of calcium acetate was $100 \mathrm{~m} M$, which equates to $1.58 \%$ in the $\beta$ stream dispersion, whereas zinc acetate usage was $25 \mathrm{mM}$ and $0.46 \%$ in molar and weight concentration. This means that calcium acetate usage was 3.43 times higher than that of zinc acetate (in weight concentration), which may have resulted in a higher concentration of ash in the calcium acetate pellet.

The weight distribution of the pellet and supernatant was calculated from the weight of supernatant divided by the initial mass of the $\beta$ stream. The higher total solids content seen in the calcium acetate treatment is due to the lower weight distribution to the pellet (23.8\% of initial mass), which means there was a larger volume of supernatant $(76.2 \%)$. The weight distribution for zinc acetate was $56.8 \%$ to the pellet and $43.2 \%$
Table 3. The apparent solubility ( $\mathrm{g}$ of salt/100 $\mathrm{g}$ of ethanol) of zinc acetate and calcium acetate under various ethanol concentrations $(70$, 80 , and $90 \%)$ and temperatures $\left(30,50\right.$, and $\left.70^{\circ} \mathrm{C}\right)$

\begin{tabular}{lccc}
\hline & \multicolumn{3}{c}{ Ethanol concentration $(\%)$} \\
\cline { 2 - 4 } Salt & 70 & 80 & 90 \\
\hline Calcium acetate $30^{\circ} \mathrm{C}$ & $3.1^{\mathrm{c}}$ & $1.2^{\mathrm{c}}$ & $0.2^{\mathrm{c}}$ \\
Zinc acetate $30^{\circ} \mathrm{C}$ & $3.2^{\mathrm{c}}$ & $2.2^{\mathrm{c}}$ & $1.6^{\mathrm{bc}}$ \\
Calcium acetate $50^{\circ} \mathrm{C}$ & $3.2^{\mathrm{c}}$ & $1.6^{\mathrm{c}}$ & $0.4^{\mathrm{c}}$ \\
Zinc acetate $50^{\circ} \mathrm{C}$ & $6.9^{\mathrm{b}}$ & $6.2^{\mathrm{b}}$ & $3.4^{\mathrm{b}}$ \\
Calcium acetate $70^{\circ} \mathrm{C}$ & $3.3^{\mathrm{c}}$ & $1.8^{\mathrm{c}}$ & $0.5^{\mathrm{c}}$ \\
Zinc acetate $70^{\circ} \mathrm{C}$ & $23.6^{\mathrm{a}}$ & $23.4^{\mathrm{a}}$ & $22.7^{\mathrm{a}}$
\end{tabular}

${ }^{a-c}$ Means with different superscript letters within the same column are significantly different at $P=0.05$.

to supernatant. The calcium acetate-precipitated pellet contained $12.1 \%$ total solids, compared with $8.6 \%$ for zinc acetate. These results indicate that calcium acetate produced a denser pellet with significantly higher total solids $(P<0.05)$. These differences in the total solids content resulted in the zinc acetate-precipitated pellet requiring more ethanol for the ethanol extraction $(8 \mathrm{~mL}$ more required for zinc acetate, as stated in Methods section). Also, the calcium acetate supernatant had a higher total solids (4.4\%) content compared with the supernatant produced by zinc acetate $(3.0 \%)$, mainly due to higher salt concentration usage. This could also indicate that more proteins were dissolved in the calcium acetate supernatant, which was confirmed by the protein concentration results.

\section{Ethanol Extraction of Lipids from the Precipitated Pellets}

Total lipid and PL recoveries of $96.7 \%$ and $97.7 \%$ were achieved from the zinc acetate-precipitated pellet, whereas $88.2 \%$ and 94.9 were achieved from the calcium acetate-precipitated pellet (Table 4). We found no significant difference in the total lipid recovery, PL recovery, or PL class composition between the lipid fractions extracted from the zinc acetate- and calcium acetate-precipitated pellets $(P>0.05)$. The PL percentage relative to the total lipid fraction was $38.7 \%$ for calcium acetate and $34.5 \%$ for zinc acetate, similar to the initial $35.0 \%$ of the $\beta$ stream lipid fraction. The PL content in the pellet was $31.2 \%$ for calcium acetate and $36.2 \%$ for zinc acetate. A significant enrichment in PL content was found in the ethanol-extracted lipid from the calcium acetate lipid fraction compared with zinc acetate $(P<0.05)$. The binding geometry and spacing of the complex between zinc and calcium with the MFGM components may have affected how efficiently PL were extracted. Zinc binds with MFGM components in a tetrahedral geometry, leading to the closest 
Table 4. Total lipid and phospholipid (PL) yield and class $^{1}$ distribution (\% of total PL) from ethanol extraction $\left(90 \% \text { ethanol at } 70^{\circ} \mathrm{C}\right)^{2}$

\begin{tabular}{lcccccrr}
\hline Salt & $\begin{array}{c}\text { Total lipid } \\
\text { recovery }(\%)\end{array}$ & $\begin{array}{c}\text { PL } \\
\text { recovery }(\%)\end{array}$ & SM & PE & PS & PI & PC \\
\hline Zinc acetate & 96.7 & 97.7 & 11.8 & 36.2 & 2.6 & 11.4 & 37.9 \\
Calcium acetate & 88.2 & 94.9 & 11.7 & 40.5 & 4.0 & 8.0 & 35.8 \\
\hline
\end{tabular}

${ }^{1} \mathrm{SM}=$ sphingomyelin; $\mathrm{PE}=$ phosphatidylethanolamine; $\mathrm{PS}=$ phosphatidylserine; $\mathrm{PI}=$ phosphatidylinositol; PC $=$ phosphatidylcholine.

${ }^{2}$ No significant difference between the two treatments, for all parameters.

distance (2.04 angstrom - smaller than the diameter of a water molecule) between the zinc MFGM complexes (Damodaran, 2010). This short distance would not easily allow for the diffusion of water or ethanol into the complex. In contrast, the calcium MFGM complex is about 3.43 angstrom (Damodaran, 2010), which may have provided more opportunity for ethanol to penetrate and extract the PL present in the calcium acetate pellet.

After the lipid was extracted from the pellets with ethanol, the ash content was quantified to determine the quantity of salt that was solubilized during the extraction. The lipid fraction from calcium acetate treatment had a significantly higher ash content $(27.9 \%)$ than that from the zinc acetate treatment (18.5\%). Under the extraction conditions $\left(90 \%\right.$ ethanol at $\left.70^{\circ} \mathrm{C}\right), 206$ $\mathrm{mL}$ of ethanol was used for the zinc acetate pellet and $198 \mathrm{~mL}$ of ethanol for the calcium acetate pellet. Such a volume of ethanol could potentially solubilize $36.8 \mathrm{~g}$ of zinc acetate and $0.8 \mathrm{~g}$ of calcium acetate. The amounts of ash in the zinc acetate- and calcium acetate-precipitated pellets were $1.8 \%$ and $3.9 \%$, respectively, which equates to 0.05 and $0.10 \mathrm{~g}$ of ash in the $25 \mathrm{~g}$ of pellet, respectively. These quantities of salt are well below the apparent solubility limit for zinc acetate and calcium acetate, meaning that all the salt present in the pellet was dissolved in ethanol. With this current extraction procedure, reducing the amount of salt being dissolved in ethanol will be difficult, and additional processing to remove salt may be required.

Zinc acetate may have health concerns because intake of greater than $225 \mathrm{mg}$ of zinc per day may suppress copper and iron absorption (Sheftel, 2000), but our newly identified calcium salt is safe and may provide additional benefit.

\section{Protein Distribution Under Optimal Precipitation Conditions}

The protein distributions of the $\beta$ stream, supernatant, and pellet were investigated using SDS-PAGE (Figure 6). The major protein classes in the initial $\beta$ stream were casein $(28$ to $35 \mathrm{kDa})$, whey $(<25 \mathrm{kDa})$, and a small quantity of MFGM proteins $(>50 \mathrm{kDa}$; Mather,
2000). The MFGM proteins represent only 1 to $2 \%$ of the total protein found in milk (Riccio, 2004), and the $\beta$ stream seems to have a similar protein profile to that of native milk. The zinc acetate supernatant contained only whey proteins, which indicates that the casein and MFGM proteins were effectively precipitated into the pellet. The calcium acetate supernatant displayed all protein classes, which confirmed our supposition that calcium acetate has a lower binding affinity toward dairy proteins. The protein composition in the pellet was similar for zinc acetate and calcium acetate, with casein and whey being the predominant proteins. The concentrations of MFGM proteins in these protein fractions were very low compared with concentrations of casein and whey proteins, as shown on the SDS-PAGE gel. Nonetheless, 2 membrane proteins were visible in the samples (Figure 6).

\section{CONCLUSIONS}

Use of zinc acetate and calcium acetate was effective for precipitating the total lipid, PL, and some proteins found in the $\beta$ stream. The lowest salt concentration treatment for zinc acetate was $25 \mathrm{mM}$, at $\mathrm{pH}$ above 6.5 at $30^{\circ} \mathrm{C}$; for calcium acetate, the effective conditions were salt concentration of 75 to $200 \mathrm{mM}$ and $\mathrm{pH}$ above 6.5 at $60^{\circ} \mathrm{C}$. For better recovery of SM, the $30^{\circ} \mathrm{C}$ calcium acetate treatment would be desirable, whereas the $60^{\circ} \mathrm{C}$ calcium acetate treatment would be desirable for PS recovery. The aqueous ethanol extraction was an effective way to remove the lipid from the precipitated pellet, and PL recovery of as high as $98 \%$ can be achieved. Although high ash content was observed in the ethanol-extracted lipid fraction, a simple further processing step can remove the salt. This work demonstrates that calcium acetate precipitation has great potential for producing valuable lipid fractions from the $\beta$ stream or from other similar dairy processing by-products.

\section{ACKNOWLEDGMENTS}

This research is supported by funds from the Midwest Dairy Association (St. Paul, MN) and the Na- 


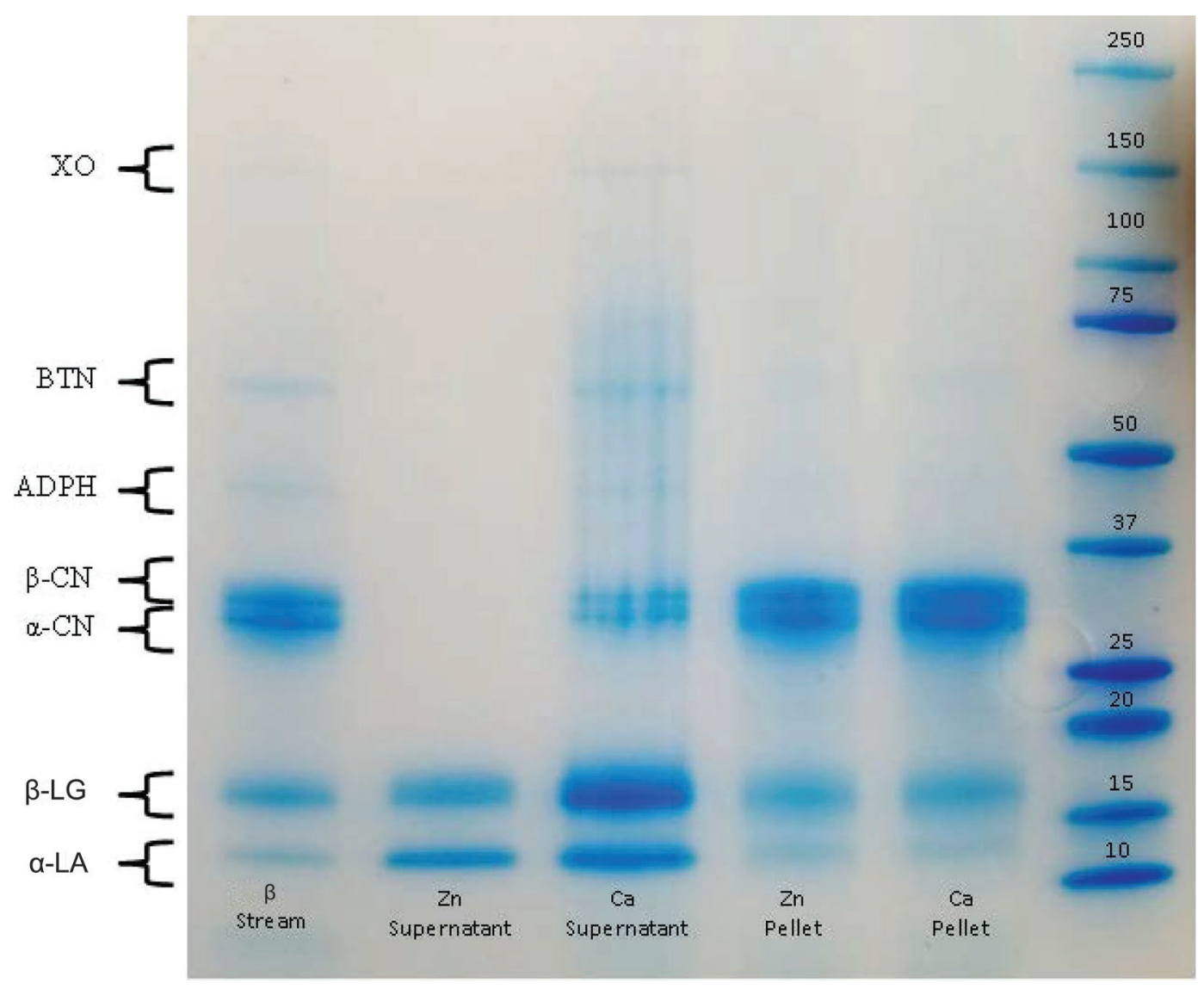

Figure 6. Sodium dodecyl sulfate-PAGE (SDS-PAGE) of the initial $\beta$ stream and supernatant and pellet samples from zinc acetate and calcium acetate treatments. $\mathrm{XO}=$ xanthine oxidase; $\mathrm{BTN}=$ butyrophilin; $\mathrm{ADPH}=$ adipophilin.

tional Dairy Council (Rosemont, IL). We are grateful to Valley Queen Cheese (Milbank, SD) for providing the $\beta$ stream for this research. This work is a product of the Iowa Agriculture and Home Economics Experiment Station (Ames), Project No. IOW04002.

\section{REFERENCES}

Binder, H., K. Arnold, A. S. Ulrich, and O. Zschorning. 2001. Interaction of $\mathrm{Zn}^{2+}$ with phospholipid membranes. Biophys. Chem. 90:57-74.

Bradford, M. M. 1976. A rapid and sensitive method for the quantitation of microgram quantities of protein utilizing the principle of protein-dye binding. Anal. Biochem. 72:248-254.

Burling, H., and G. Graverholt. 2008. Milk-A new source for bioactive phospholipids for use in food formulations. Lipid Technol. 20:229-231.

Carunchia Whetstine, M. E., M. A. Drake, and A. Croissant. 2005. Characterization of dried whey protein concentrate and isolate flavor. J. Dairy Sci. 88:3826-3839.

Christie, W. W., and X. Han. 2010. Lipid Analysis: Isolation, Separation, Identification and Lipidomic Analysis. 4th ed. The Oily Press, Bridgwater, UK.

Contarini, G., and M. Povolo. 2013. Phospholipids in milk fat: Composition, biological and technological significance, and analytical strategies. Int. J. Mol. Sci. 14:2808-2831.
D'Acapito, F., I. Emelianov, A. Rlini, P. Cavatorata, A. Gliozzi, V. Minicozzi, S. Morante, P. L. Solari, and R. Rolandi. 2002. Total external reflection X-ray absorption spectroscopy reveals a zinc coordination shell in phospholipid Langmuir-Blodgett films. Langmuir 18:5277-5282.

Damodaran, S. 2005. Protein stabilization of emulsions and foams. J. Food Sci. 70:R54-R66.

Damodaran, S. 2010. Zinc-induced precipitation of milk fat globule membranes: A simple method for the preparation of fat-free whey protein isolate. J. Agric. Food Chem. 58:11052-11057.

Deeth, H. C. 1997. The role of phospholipids in the stability of milk fat globules. Aust. J. Dairy Technol. 52:44-46.

Dewettinck, K., R. Rombaut, N. Thienpont, T. Trung Le, K. Messens, and J. Van Camp. 2008. Nutritional and technological aspects of milk fat globule membrane material. Int. Dairy J. 18:436-457.

Folch, J., M. Lees, and G. H. Stanley. 1957. A simple method for the isolation and purification of total lipids from animal tissues. J. Biol. Chem. 226:497-509.

Fong, B. Y., C. S. Norris, and A. K. H. MacGibbon. 2007. Protein and lipid composition of bovine milk-fat-globule membrane. Int. Dairy J. $17: 275-288$.

Jimenez-Flores, R., and G. Brisson. 2008. The milk fat globule membrane as an ingredient: Why, how, when? Dairy Sci. Technol. $88: 5-18$.

Mather, I. H. 2000. A review and proposed nomenclature for major proteins of milk-fat globule membrane. J. Dairy Sci. 83:203-247.

Morr, C. V., and E. Y. W. Ha. 1991. Off-flavors of whey protein concentrates: A literature review. Int. Dairy J. 1:1-11. 
Pepeu, G., I. M. Pepeu, and L. Amanducci. 1996. A review of phosphatidylserine pharmacological and clinical effects. Is phosphatidylserine a drug for the ageing brain? Pharmacol. Res. 33:73-80.

Price, N., T. Fei, S. Clark, and T. Wang. 2018. Extraction of phospholipids from a dairy by-product (whey protein phospholipid concentrate) using ethanol. J. Dairy Sci. 101:8778-8787.

Primacella, M., T. Wang, and N. C. Acevedo. 2018. Use of reconstituted yolk systems to study the gelation mechanism of frozen-thawed hen egg yolk. J. Agric. Food Chem. 66:512-520.

Riccio, P. 2004. The proteins of the milk fat globule membrane in the balance. Trends Food Sci. Technol. 15:458-461.

Rodriguez-Alcalá, L. M., and J. Fontecha. 2010. Major lipid classes separation of buttermilk, and cows, goats and ewes milk by high performance liquid chromatography with an evaporative light scattering detector focused on the phospholipid fraction. J. Chromatogr. A 1217:3063-3066.

Rombaut, R., J. V. Camp, and K. Dewettinck. 2006. Phospho- and sphingolipid distribution during processing of milk, butter and whey. Int. J. Food Sci. Technol. 41:435-443.
Rombaut, R., and K. Dewettinck. 2006. Properties, analysis and purification of milk polar lipids. Int. Dairy J. 16:1362-1373.

Rombaut, R., and K. Dewettinck. 2007. Thermocalcic aggregation of milk fat globule membrane fragments from acid buttermilk cheese whey. J. Dairy Sci. 90:2665-2674.

Sheftel, O. 2000. Indirect Food Additives and Polymers Migration and Toxicology. 1st ed. CRC Press, Boca Raton, FL.

Wang, H., L. Yao, and T. Wang. 2014. Extraction of phospholipids from structured dry egg yolk. J. Am. Oil Chem. Soc. 91:513-520.

\section{ORCIDS}

Stephanie Clark (1) https://orcid.org/0000-0002-3253-3042

Tong Wang (ํ) https://orcid.org/0000-0002-6667-6498 